\title{
Condition and Sperm Characteristics of Perch Perca fluviatilis inhabiting Boreal Lakes Receiving Metal Mining Effluents
}

\author{
Juha Karjalainen $^{1}$ (D ) Hanna E. Arola ${ }^{1} \cdot$ Jaana Wallin $^{1} \cdot$ Ari Väisänen ${ }^{2} \cdot$ Anna K. Karjalainen $^{1}$
}

Received: 3 March 2020 / Accepted: 1 July 2020 / Published online: 21 July 2020

(c) The Author(s) 2020

\begin{abstract}
One of the world's largest, but low-grade, sulfide nickel deposits in northeastern Finland has been exploited by a bioheapleaching technology since 2008. Bioheapleaching is a relatively new, cost-effective technology, but humid climate, e.g., in boreal temperate environments, causes challenges to the management of the water balance in the ore heaps with wide catchment area, and the mining effluents have caused substantial metal and salting contamination of the receiving waterbodies. In our study, the impacts of metal-extracting bioheapleaching mine effluents on muscle and liver element concentrations, body condition, liver and testes mass, and sperm count and motility of male perch Perca fluviatilis were analysed. Liver, testes, and carcass mass of perch in relation to their length were lower in the mining-impacted lakes than in the reference lake, which may be due to the metal contamination, food availability, and energy demand under multistressor conditions. The sperm counts of the males in the mining-impacted lakes were lower, but the endurance of their sperm motility was longer than the endurance of sperm of the reference males. These findings suggested that the condition and sperm characteristics of perch were altered in lakes receiving metal mining effluents. Measured variables seem to be useful indicators for metal mining impacts on freshwater fish but only if high natural variation in these characteristics can be controlled by multiyear monitoring scheme.
\end{abstract}

One of the world's largest, but low-grade, sulfide nickel deposit located in Talvivaara, northeastern Finland has been exploited by a bioheapleaching technology since 2008 (Riekkola-Vanhanen 2013). The mining effluents have caused substantial metal and salting contamination of the receiving waterbodies (Salmelin et al. 2017). Bioheapleaching is a relatively new, cost-effective technology, but in boreal temperate environments, the high precipitation causes challenges to the management of the water balance in the ore heaps with very large surface area (Riekkola-Vanhanen 2013). In late 2012, due to the rainy summer and autumn, the gypsum pond leakage at the mine caused severe increase in metal concentrations and salinity of the receiving water bodies with concentrations that are known to be harmful for aquatic biota (Arola et al. 2017). There is evidence from

Juha Karjalainen

juha.s.karjalainen@jyu.fi

1 Department of Biological and Environmental Science, University of Jyväskylä, P.O. Box 35, 40014 Jyväskylä, Finland

2 Department of Chemistry, University of Jyväskylä, P.O. Box 35, 40014 Jyväskylä, Finland one of the mining-impacted (MI) lakes that the mining effluent from the bioheapleaching process induced water-quality deterioration and has decreased the species richness and diversity of cladoceran and diatom communities (Leppänen et al. 2017).

In different fish species, lower growth rates (Eastwood and Couture 2002; Rajotte and Couture 2002), condition factors (Eastwood and Couture 2002; Levesque et al. 2002; Rajotte and Couture 2002), and hepatosomatic indexes (Rajotte and Couture 2002) have been observed in fish inhabiting metal polluted waters with increased tissue metal concentrations (Rajotte and Couture 2002). Furthermore, metal contamination may lead to higher energetic costs for fish (Sherwood et al. 2000) and, for example, impair the function of the olfactory sensory neurons affecting the antipredatory behavior and feeding of fish (Dew et al. 2014). Metal pollution can deteriorate physiological condition of fish in many ways (Rajotte and Couture 2002) and reduce the genetic diversity within a fish population and the population's ability to withstand future environmental changes (Bourret et al. 2008). Conversely, Durrant et al. (2011) proposed that convergent adaptive evolutionary processes might lead to metal resistance in a number of 
geographically distinct brown trout (Salmo trutta) populations in southwest England.

Many metals, e.g., copper $(\mathrm{Cu})$, zinc $(\mathrm{Zn})$, cadmium $(\mathrm{Cd})$, and iron $(\mathrm{Fe})$, accumulate mainly in the liver of fish, irrespective of the uptake route (Jezierska and Witeska 2006; El-Moselhy et al. 2014). In most cases, the lowest concentrations of metals in fish are in muscle, whereas metal levels in the liver rapidly increase during exposure and remain high for a long time during depuration when other organs are already cleared (Jezierska and Witeska 2006; El-Moselhy et al. 2014). El-Moselhy et al. (2014) showed that fish exhibited wide, interspecific variations in metals accumulation in all organs. Significant seasonal effects on tissue metal concentrations in fish also have been detected (Couture et al. 2008). Metal concentrations in fish usually follow the ranking: $\mathrm{Fe}>\mathrm{Zn}>$ lead $(\mathrm{Pb})>\mathrm{Cu}>\mathrm{Cd}>$ mercury $(\mathrm{Hg})$, but environmental factors affect the uptake and accumulation of metals in fish (Jezierska and Witeska 2006). Metabolic turnover and growth rate affects the accumulation of metals (Honda et al. 1983). Furthermore, water acidification also effects substantially the metal bioaccumulation by changing the solubility of metal compounds (Jezierska and Witeska 2006). Low pH and low alkalinity correlate with high concentrations of metals in liver and dissolved organic material reduces the bioavailability by complexing metals (Eastwood and Couture 2002).

Gonadosomatic indexes of both male and female fish also can be lower in metal-polluted environments (Pyle et al. 2005). Sperm exposure to metals, such as $\mathrm{Cd}, \mathrm{Cu}$, $\mathrm{Hg}$, or Pb (Kime et al. 1996; Rurangwa et al. 1998; Lahnsteiner et al. 2004), is known to impair the sperm motility and/or alter the sperm velocity. However, the impact of decreased sperm motility on fertilization success may become evident only when the sperm-to-egg ratio is lowered to a suboptimal level, whereas with sufficient spermto-egg ratio, the impact on fertilization success can be masked by the total number of motile sperm (Rurangwa et al. 1998).

Thus, in the spring of 2013 and 2014, we investigated whether mature male perch (Perca fluviatilis), living in the lakes (MI lakes) receiving the effluents from the bioheapleaching process from nickel mining, showed signs of physiological stress related to the mining effluent contamination. We evaluated whether their condition and reproductive potential was affected by the mining effluent loading. Condition of fish was analysed by measuring the wet mass of carcass and liver in relation to the total length of fish. Potential effects on reproduction were studied by measuring the wet mass of testes, sperm count, and motility. We also measured element concentrations in the muscles and livers of the male perch.
Materials and Methods

\section{Study Lakes}

Three of the four selected study lakes (lakes Jormasjärvi, Kivijärvi, and Laakajärvi) have received effluent loading from the Talvivaara/Terrafame Sotkamo Mine (Fig. 1). The Talvivaara Sotkamo Mine is located at the border of the watersheds of Oulujoki and Vuoksi, and the mining effluents were discharged into both watersheds. Jormasjärvi is a medium-sized humic lake, whereas Kivijärvi and Laakajärvi are humus-rich lakes, forestry being the main land use type in the catchment areas of all those three lakes (Finnish Environment Institute Database 2017). Of the three lakes, Kivijärvi was the most severely impacted and its ecological status was classified as "bad" (Finnish Environment Institute Database 2017). Both Jormasjärvi and Laakajärvi were moderately impacted by the mining effluents and their ecological statuses were classified as "good" (Finnish Environment Institute Database 2017). The reference lake Kiantajärvi is a medium-sized humic lake with a good ecological status, forestry being the main land use type in its catchment area (Finnish Environment Institute Database 2017).

\section{Water Quality and Sediment}

Epilimnion water temperature, dissolved oxygen, $\mathrm{pH}$, and specific conductance of the sampling sites was measured with YSI6600 multiparameter sonde each time when sample fish were collected. Filtered water samples for dissolved element determination were collected once from each lake in both years. The samples were collected from the shore approximately from $0.2-\mathrm{m}$ depth and filtered $(0.45 \mu \mathrm{m}$, Whatman PVFD w/PP) into metal-free plastic tubes and acidified immediately with $0.5 \mathrm{~mL}$ of nitric acid in the field. The water samples were stored at the dark at $+4{ }^{\circ} \mathrm{C}$ until analysis of cadmium $(\mathrm{Cd})$, iron $(\mathrm{Fe})$, manganese $(\mathrm{Mn})$, nickel $(\mathrm{Ni})$, and zinc ( $\mathrm{Zn})$ by inductively coupled plasma-optical emission spectrometry (ICP-OES, Optima 8300, Perkin-Elmer). The limits of quantification (LOQ) for each element were defined according to USEPA (2001). The relative standard deviation limit (RSD) was $10 \%$ for all the elemental measurements. Samples were analysed in 2013 and 2014. The water quality data collected in this study was complemented with water quality data for the sampling years 2000-2014 from the Finnish Environment Institute Water Quality Database (2017). Water samples for dissolved organic carbon (DOC) analysis were collected into glass bottles and stored at the dark at $+4{ }^{\circ} \mathrm{C}$ until analysed with Shimadzu Carbon Analyser. 
Fig. 1 Location of the reference (Kiantajärvi) and mining impacted study lakes (Kivijärvi, Laakajärvi and Jormasjärvi) in Oulujoki (O) and Vuoksi (V) watersheds in Finland. The Talvivaara mine district is indicated in diagonal fill and lakes and streams in grey. Direction of water flow from the mine district to study lakes is shown by arrows. Map data: National Land Survey of Finland,

National Database of Regional Land Use Plans, Finnish Environment Institute

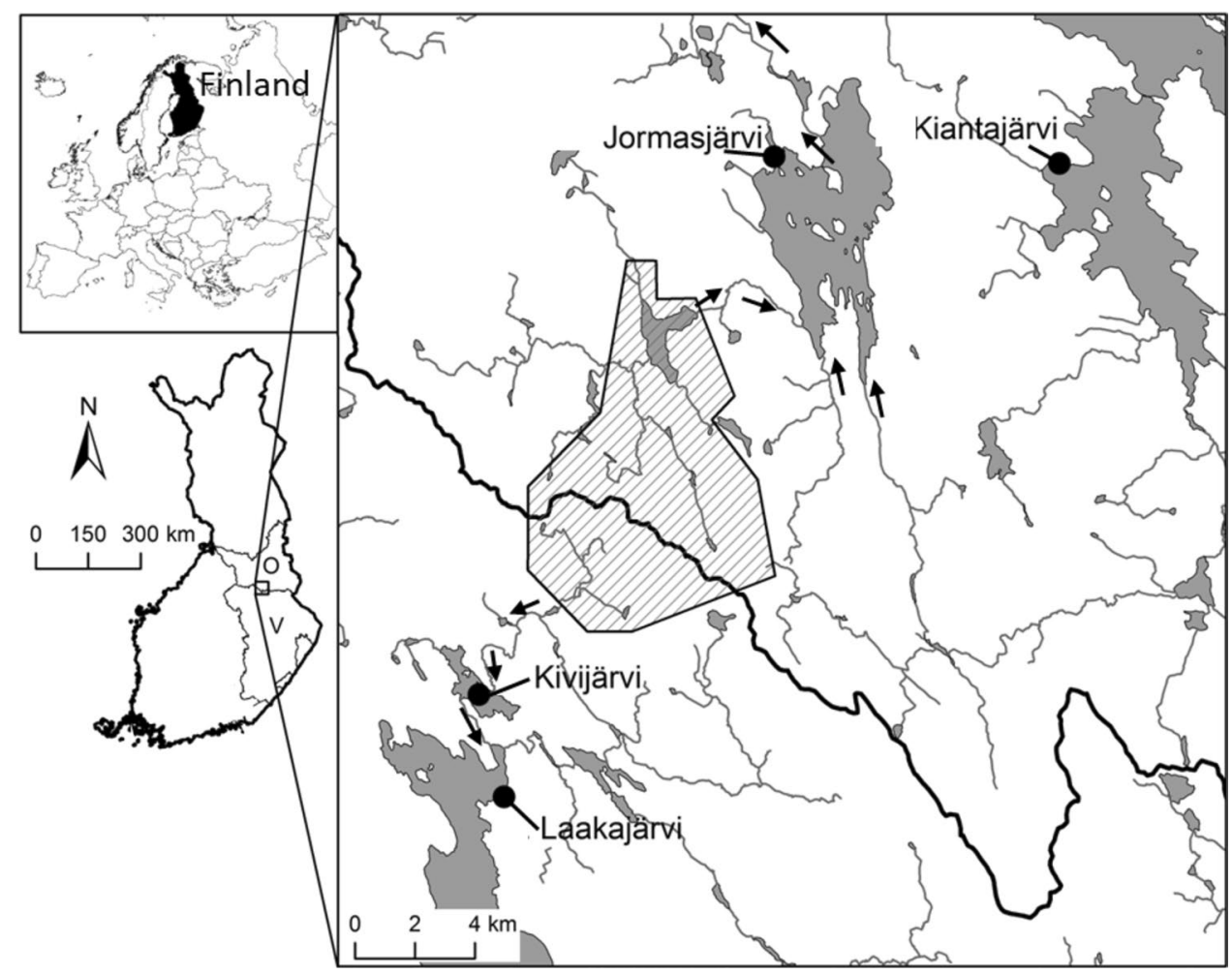

Surface sediment samples $(0-5 \mathrm{~cm})$ were taken with a Sandman gravity corer from the sampling site accumulation basins (Wallin 2018). Eight to nine replicate sediment cores were combined to one homogenous bulk sample immediately on the sampling site. The sediment samples were stored at the dark at $+4{ }^{\circ} \mathrm{C}$ until analysis. Approximately $0.5 \mathrm{~g}$ of dried sediment was weighed into $50-\mathrm{mL}$ plastic tubes. Samples were sonicated (ELMA Transonic $820 / \mathrm{H}$ or Bandelin Sonorex RK 512/H) three to four times for $3 \mathrm{~min}$ at $50{ }^{\circ} \mathrm{C}$. After sonication, the sediment samples were filtered (Whatman no. 41), and the extract was diluted 122 to $50 \mathrm{~mL}$ with ultrapure water. Sediment samples were analysed for element $(\mathrm{Cd}, \mathrm{Fe}, \mathrm{Mn}, \mathrm{Ni}, \mathrm{Z})$ concentrations by ICP-OES (PerkinElmer Optima 8300).

\section{Perch Sampling Protocol in 2013 and 2014}

Mature male perch were caught with fish traps (Weke traps, Weke-Katiskat Oy, https://www.weke.fi/en/) in May 2013 and 2014. In 2013, the perch were caught in the beginning of the spawning season in order to obtain representative sperm samples. In 2014, the sperm variables were not analysed, and perch were caught before the spawning season in May. In 2013, total length and wet mass of carcass (body excluding the liver, testes, and alimentary canal), liver, and testes of the perch were measured. Also, the sperm count, motility, and velocity, muscle, and liver element concentrations were analysed in 2013. Perch were transported to the field laboratory in aerated plastic water tanks containing their natal lake water, killed with a blow to the head, and measured at the field laboratory.

In 2014, only total length and wet mass of carcass, liver, and testes of the perch were measured. The perch were killed with a blow to the head and measured either in the field laboratory immediately after catching, or stored at $-20^{\circ} \mathrm{C}$ and measured later. The frozen perch were thawed at $+4{ }^{\circ} \mathrm{C}$ or in a water bath in plastic bags and measured thereafter. Number of fish in sampling years and lakes and their sizes and ages are given in Table 1. Age of the fish was determined from the scales.

\section{Tissue Element Concentrations}

Fish were kept on ice during the dorsal muscle and liver sampling, and the samples were stored in plastic bags at $-20{ }^{\circ} \mathrm{C}$ until analysed. For the tissue metal concentration analyses, the frozen samples were thawed at room temperature, weighed, and dried at $+105^{\circ} \mathrm{C}$ for $24 \mathrm{~h}$. For the analyses, dried muscle and liver (61-94 mg and 8-78 mg, respectively) were weighed into plastic tubes. The tissue samples were digested by moistening the samples with a few drops of ultrapure water, adding $3 \mathrm{~mL}$ (sample dry weight $>40 \mathrm{mg}$ ) or $1.5 \mathrm{~mL}$ (sample $<40 \mathrm{mg}$ ) of aqua regia $\left(\mathrm{HNO}_{3}: \mathrm{HCl}, 1: 3\right.$, $\mathrm{v}: \mathrm{v})$ into each sample and sonicating the samples for $3 \mathrm{~min}$ at $45-60^{\circ} \mathrm{C}$ (De La Calle et al. 2009). The digested samples were filtered (Whatman 41) and filled up to the final volume 
Table 1 Total length $(\mathrm{cm}$, mean \pm standard error SE), total wet mass $(\mathrm{g}$, mean $\pm \mathrm{SE})$, wet mass of testes $(\mathrm{g}$, mean $\pm \mathrm{SE})$, wet mass of carcass $(\mathrm{g}$, mean $\pm \mathrm{SE})$, wet mass of liver $(\mathrm{g}$, mean $\pm \mathrm{SE})$, and median

\begin{tabular}{|c|c|c|c|c|c|c|c|c|}
\hline & Kianta 2013 & Jormas 2013 & Laaka 2013 & Kivi 2013 & Kianta 2014 & Jormas 2014 & Laaka 2014 & Kivi 2014 \\
\hline Total length & $\begin{array}{l}17.0 \pm 0.5 \\
(14)\end{array}$ & $\begin{array}{l}16.5 \pm 0.4 \\
(26)\end{array}$ & $\begin{array}{l}13.1 \pm 0.5 \\
\quad(10)\end{array}$ & $\begin{array}{l}13.8 \pm 0.5 \\
(16)\end{array}$ & $\begin{array}{l}17.5 \pm 0.4 \\
(36)\end{array}$ & $\begin{array}{l}15.3 \pm 0.5 \\
(53)\end{array}$ & $\begin{array}{l}12.6 \pm 0.2 \\
(20)\end{array}$ & $13.7 \pm 0.2(79)$ \\
\hline Total mass & $\begin{array}{l}47.4 \pm 4.5 \\
(14)\end{array}$ & $\begin{array}{l}41.2 \pm 2.8 \\
\quad(26)\end{array}$ & $\begin{array}{l}18.2 \pm 2.4 \\
(10)\end{array}$ & $\begin{array}{l}25.2 \pm 2.9 \\
(16)\end{array}$ & $\begin{array}{l}59.5 \pm 3.6 \\
(36)\end{array}$ & $\begin{array}{l}39.2 \pm 3.3 \\
(53)\end{array}$ & $\begin{array}{l}18.0 \pm 0.7 \\
(20)\end{array}$ & $23.7 \pm 1.1(79)$ \\
\hline Testes mass & $2.4 \pm 0.2(14)$ & $1.8 \pm 0.2(17)$ & $0.5 \pm 0.1(10)$ & $0.7 \pm 0.1(16)$ & $2.4 \pm 0.2(36)$ & $1.4 \pm 0.2(53)$ & $0.8 \pm 0.1(19)$ & $0.8 \pm 0.1(77)$ \\
\hline Carcass mass & $\begin{array}{l}43.1 \pm 4.1 \\
\quad(14)\end{array}$ & $\begin{array}{l}37.4 \pm 2.9 \\
(17)\end{array}$ & $\begin{array}{l}23.6 \pm 2.8 \\
(10)\end{array}$ & $\begin{array}{l}17.0 \pm 2.2 \\
(10)\end{array}$ & $\begin{array}{l}53.7 \pm 3.3 \\
(36)\end{array}$ & $\begin{array}{l}35.6 \pm 3.0 \\
(53)\end{array}$ & $\begin{array}{l}21.3 \pm 1.0 \\
(79)\end{array}$ & $16.2 \pm 0.7(20)$ \\
\hline Liver mass & $0.5 \pm 0.2(5)$ & $\begin{array}{l}0.4 \pm 0.03 \\
(17)\end{array}$ & $\begin{array}{l}0.13 \pm 0.02 \\
\quad(10)\end{array}$ & $\begin{array}{l}0.19 \pm 0.03 \\
\quad(16)\end{array}$ & $\begin{array}{l}0.78 \pm 0.1 \\
\quad(36)\end{array}$ & $\begin{array}{l}0.50 \pm 0.1 \\
(53)\end{array}$ & $\begin{array}{l}0.17 \pm 0.02 \\
\quad(20)\end{array}$ & $\begin{array}{l}0.19 \pm 0.01 \\
\quad(79)\end{array}$ \\
\hline Age & $3(3-5)$ & $5(3-6)$ & $4(3-6)$ & $4(3-6)$ & $4(2-5)$ & $4(2-6)$ & $4(3-6)$ & $4(3-6)$ \\
\hline $\begin{array}{l}\text { Fish in sperm } \\
\text { analysis }\end{array}$ & 14 & 24 & 10 & 13 & - & - & - & - \\
\hline
\end{tabular}

Number of fish measured is represented in parentheses. Number of males in the sperm analysis is given in the last row

-No samples taken for sperm analysis in 2014

of $20 \mathrm{~mL}$ (sample dry weight $>40 \mathrm{mg}$ ) or $10 \mathrm{~mL}$ (sample dry weight $<40 \mathrm{mg}$ ) with ultrapure water. The concentrations of cadmium (Cd), iron (Fe), manganese (Mn), nickel (Ni), sulfur $(\mathrm{S})$, and zinc $(\mathrm{Zn})$ were analysed with ICP-OES (Optima 8300, Perkin-Elmer), and the LOQs and RSD requirements were the same as for the water samples. Additionally, the muscle Ni concentrations were analysed with electrothermal atomic absorption spectrometer (ETAAS, Model Aanalyst 800 equipped with an AS-800 autosampler, Perkin-Elmer) in order to reach lower analysis LOQs of $0.31 \mu \mathrm{g} \mathrm{L}^{-1}$ for Ni. Concentrations $\leq \mathrm{LOQ}\left(\mathrm{mg} \mathrm{L}^{-1}\right)$ or with $\mathrm{RSD}>10 \%$ were discarded from the calculations. In muscle tissue, $2 \%$ of $\mathrm{Fe}$, $2 \%$ of $\mathrm{S}, 23 \%$ of $\mathrm{Ni}$, and $73 \%$ of Mn samples were discarded because of LOQ and RSD limits. Cd concentrations in muscle and Ni concentration in liver was largely under LOQ, and thus, all samples were excluded. The quality assurance of the method was performed by the analysis of blank samples and certified reference materials TORT-2 (Lobster hepatopancreas) and DOLT-4 (Dogfish liver) supplied by the National Research Council (NRC). Samples were analysed in 2013 and 2014. We reported in this study the $\mathrm{Cd}, \mathrm{Fe}, \mathrm{Mn}, \mathrm{Ni}, \mathrm{Zn}$, and $\mathrm{S}$ results, because these elements are the main components in the ore effluents.

\section{Sperm Analyses}

Sperm counts, velocity, and proportion of motile sperm of males from reference lakes and from the impacted lakes were analysed with Proiser ISASv $1{ }^{\circledR}$ CASA system. The sperm counts represent one random microscopic field of vision. The motility was measured as the velocity of a sperm head along the total trajectory (VCL, $\mu \mathrm{m} \mathrm{s}^{-1}$ ), and the velocity as the velocity of a sperm head along a straight line between (minimum-maximum) age (years) of sampled fish in 2013 and 2014 in the reference lake (Kianta) and the mining impacted lakes 
marginal means with the Least significant difference (LSD) procedure. The impact of the fish body size on the tissue element concentrations was tested as well by inserting the $\log _{10}$-transformed wet mass of the carcass as a covariate, but because its effect was insignificant on all the variables, it was excluded from the final analyses. Homogeneity of variance was observed in all models of the elements (Levene, $p>0.05$ ). All $\log _{10}$-transformed variables of the elements were normally distributed (Shapiro-Wilk, $p>0.05$ ). Pearson correlation was used to analyze correlation between $\log _{10}$-trasformed element concentrations, and liver and testes masses from the pooled data of all lakes together.

An ANCOVA was used in analyzing the mining impact on the condition of male perch between lakes. The dependent variables were wet mass ( $g$ ) of carcass (excluding alimentary canal, liver, and testes), liver, and testes, which all were $\log _{10}$-transformed for the analyses. To analyze the carcass-mass-at-length of the fish, the $\log _{10}$-transformed total length of perch was set as a covariate and the sampling year and lake as the independent factors. Transformation was due to nonlinear relationships between the total length and the masses. All pairwise comparisons were made based on the estimated marginal means with the LSD procedure. Only individuals with wet body mass below $100 \mathrm{~g}$ were included into the measurements and analyses in order to harmonize the fish size between lakes. Homogeneity of variance was tested by the Levene test, and the normality test was done by Shapiro-Wilk test. Homogeneity of variance was observed in all models (Levene, $p>0.05$ ), except in the analysis of carcass mass with $\log _{10}$-transformation (Levene, $p=0.01$ ). We interpreted that this minor discrepancy in assumption underlying in the models did not disturb our overall interpretation. All three $\log _{10}$-transformed variables (carcass mass, testes, liver) were normally distributed (Shapiro-Wilk, $p>0.05$ ).

The mean individual total sperm count was calculated from the mean sperm count of all activation water types at both 10 and $20 \mathrm{~s}$ measuring frame. An ANOVA was used in analyzing the mining impact on the sperm count (no. of sperm per a microscope frame). All pairwise comparisons were made based on the estimated marginal means with a LSD procedure. Also, the relation between the size of the male (total length) as well as the proportion of motile sperm on the total sperm count was inspected. $\log _{10}$-transformed total length was used firstly as a covariate in the ANCOVA but was excluded from the final ANOVAs, because the effect of total length was not statistically significant in the models. The correlations between the sperm count and the wet mass of the males or the sperm count and the proportion of active sperm in samples were analyzed by Spearman's correlation coefficient.

To inspect the differences in sperm motility among the different activation waters, a repeated measures ANOVA and Bonferroni multiple comparison procedure was used: within-subject factor was the activation water (Cd solution, artificial freshwater, and lake water) and between-subject factor sampling time (10- and 20-s sampling). The sperm motility (proportion of motile sperm with arcsine-transformation) and velocity (VSL) differences among the males from the different lakes were analysed only from the lake water activated sperm and separately for both 10- and 20-s measurements. Static spermatozoa were excluded from the velocity analyses. A lake-wise ANOVA was used in analyzing the mining impact on the proportion of motile sperm and sperm velocity. All pairwise comparisons were made based on the estimated marginal means with LSD procedure. Homogeneity of variance was observed in both models (Levene, $p>0.05$ ), except in the analysis of proportion of motile sperm with arcsine-transformation at $10 \mathrm{~s}$ (Levene, $p=0.027)$. This minor discrepancy in assumption underlying in the models was accepted. Both sperm motility and velocity was normally distributed (Shapiro-Wilk, $p>0.05$ ). All of the statistical analyses were made with IBM SPSS 24.

\section{Results}

\section{Water Quality}

Surface water temperature, dissolved oxygen, $\mathrm{pH}$, and specific conductance of the sampling sites during the catching fish was given in Table 2. The long-term trends in the water quality (database of Finnish Environment Institute and own measurements) showed that the electric conductivity

Table 2 Mean water quality of surface water ( $<1 \mathrm{~m}$ depth) (mean, $n=1-3)$ of the study lakes in spring 2013 and 2014: water temperature $\left({ }^{\circ} \mathrm{C}\right)$, $\mathrm{pH}$, oxygen concentration $\left(\mathrm{mg} \mathrm{L}^{-1}\right)$, oxygen saturation $(\%)$, dissolved organic compounds (DOC, $\mathrm{mg} \mathrm{L}^{-1}$ )

\begin{tabular}{lcccccccc}
\hline & Kianta 2013 & Jormas 2013 & Laaka 2013 & Kivi 2013 & Kianta 2014 & Jormas 2014 & Laaka 2014 & Kivi 2014 \\
\hline Temperature & 14.3 & 14.1 & 11.0 & 16.6 & 8.0 & 6.9 & 6.8 & 7.3 \\
pH & 6.4 & 6.4 & 5.8 & 6.4 & 6.6 & 6.1 & 5.5 & 6.4 \\
Oxygen & 11.0 & 11.0 & 9.8 & 9.2 & 11.5 & 11.2 & 10.6 & 10.5 \\
Oxygen $\%$ & 106.5 & 106.3 & 88.8 & 93.8 & 96.2 & 92.0 & 87.0 & 87.1 \\
DOC & 10.5 & 9.2 & 9.2 & 8.0 & 10.7 & 9.2 & 13.7 & 10.5 \\
\hline
\end{tabular}


of the lake water started to increase in the MI study lakes, Jormasjärvi, Laakajärvi, and Kivijärvi, roughly from 2010 onwards after the beginning of the mining in 2008 (Fig. 2a epilimnion, $b$ hypolimnion). Of these three lakes, especially in Kivijärvi, the conductivity increased rapidly after 2010. Simultaneously, in the three MI lakes, the seasonal $\mathrm{SO}_{4}$ concentrations in both the epilimnion and hypolimnion increased (Fig. 2c, d). The highest seasonal mean concentrations of dissolved $\mathrm{Fe}, \mathrm{Zn}, \mathrm{Mn}, \mathrm{Cd}$, and $\mathrm{Ni}$ were observed in the hypolimnion of Kivijärvi, and these elements were elevated in the sediment of the MI lakes compared with the reference lake (Table 3).

\section{Tissue Element Concentrations}

The $\mathrm{Fe}, \mathrm{Mn}$, and $\mathrm{Cd}$ concentrations in the perch liver were significantly different among lakes (Table 4). The Fe concentration of the perch livers in the reference lake Kiantajärvi differed significantly from the Fe concentrations in the MI lakes and the Fe concentrations increased with severity of
Fig. 2 Mean seasonal conductivity and $\mathrm{SO}_{4}$ concentration from spring 2000 to spring 2014 in the epilimnion (a and c depth layer $0-2 \mathrm{~m}$ from the surface) and hypolimnion (b and $\mathbf{d}$, depth layer 0-2 $\mathrm{m}$ above the lake bottom) in Kiantajärvi (reference lake), Jormasjärvi, Laakajärvi and Kivijärvi. The solid vertical line indicates the beginning of the mining operations in spring 2008 and the dashed line the gypsum pond leakage at the mine in autumn 2012. Data sources from Finnish Environment Institute Water Quality Database (2017). Hypolimnion data for Kiantajärvi are not available for whole monitoring period
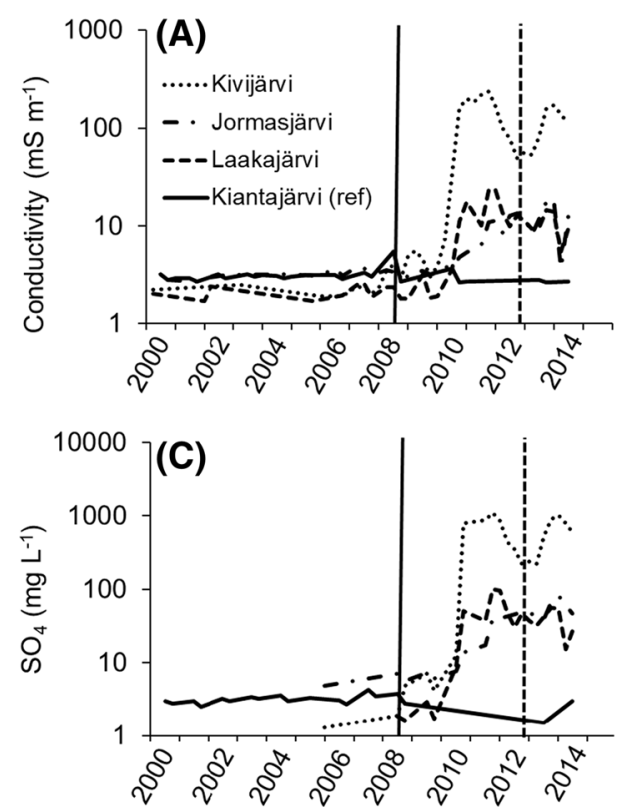
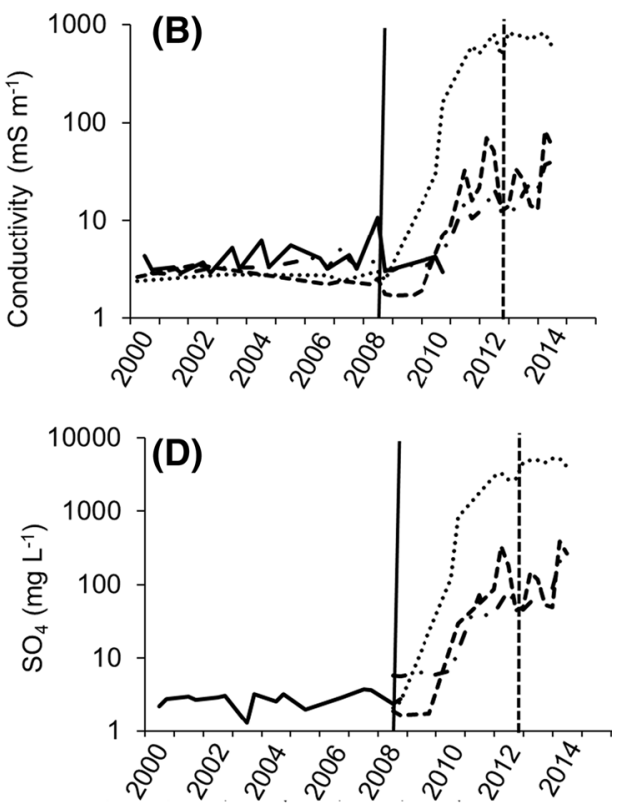

Table 3 Mean concentrations ( \pm standard error) of Fe, $\mathrm{Zn}, \mathrm{Mn}, \mathrm{Cd}$, and $\mathrm{Ni}$ in the epilimnion ( $<1 \mathrm{~m}$ depth) and hypolimnion ( $1 \mathrm{~m}$ from the bottom) in the study lakes in 2010-2014 and in the sediment in 2015

\begin{tabular}{|c|c|c|c|c|c|c|}
\hline Zone & Lake & $\mathrm{Fe} \mathrm{mg} \mathrm{L}^{-1}$ & $\mathrm{Zn} \mu \mathrm{g} \mathrm{L}^{-1}$ & $\mathrm{Mn} \mathrm{mg} \mathrm{L}^{-1}$ & $\mathrm{Cd} \mu \mathrm{g} \mathrm{L}^{-1}$ & Ni $\mu g L^{-1}$ \\
\hline \multirow[t]{4}{*}{ Epilimnion } & Kianta & $0.59 \pm 0.03$ & $<$ LOQ & $0.11 \pm 0.02$ & - & $12.65 \pm 0.05$ \\
\hline & Jormas & $0.55 \pm 0.08$ & $33.45 \pm 5.29$ & $0.07 \pm 0.01$ & $0.09 \pm 0.01$ & $12.34 \pm 1.69$ \\
\hline & Laaka & $0.80 \pm 0.25$ & $11.77 \pm 2.36$ & $0.37 \pm 0.12$ & $0.03 \pm 0.01$ & $5.91 \pm 1.67$ \\
\hline & Kivi & $0.62 \pm 0.10$ & $29.38 \pm 4.16$ & $4.53 \pm 1.21$ & $0.09 \pm 0.03$ & $32.49 \pm 4.54$ \\
\hline \multirow[t]{4}{*}{ Hypolimnion } & Kianta & $0.59 \pm 0.04$ & $<$ LOQ & - & - & $12.7 *$ \\
\hline & Jormas & $0.88 \pm 0.17$ & $57.70 \pm 11.91$ & $0.70 \pm 0.21$ & $0.14 \pm 0.01$ & $15.5 \pm 1.09$ \\
\hline & Laaka & $0.75 \pm 0.06$ & $11.99 \pm 2.23$ & $1.19 \pm 0.52$ & $0.07 \pm 0.03$ & $11.4 \pm 2.18$ \\
\hline & Kivi & $61.93 \pm 15.87$ & $155.27 \pm 83.18$ & $58.83 \pm 16.57$ & $0.44 \pm 0.22$ & $373.20 \pm 153.95$ \\
\hline Zone & Lake & $\mathrm{Fe} \mathrm{mg} \mathrm{g}^{-1}$ & $\mathrm{Zn} \mathrm{mg} \mathrm{g}^{-1}$ & $\mathrm{Mn} \mathrm{mg} \mathrm{g}^{-1}$ & $\mathrm{Cd} \mathrm{mg} \mathrm{kg}^{-1}$ & $\mathrm{Ni} \mathrm{mg} \mathrm{g}^{-1}$ \\
\hline \multirow[t]{4}{*}{ Sediment } & Kianta & $18.14 \pm 2.04$ & $0.09 \pm 0.01$ & $1.26 \pm 0.13$ & $1.43 \pm 0.37$ & $0.02 \pm 0.01$ \\
\hline & Jormas & $38.09 \pm 1.78$ & $0.46 \pm 0.04$ & $1.94 \pm 0.19$ & $5.52 \pm 0.51$ & $0.10 \pm 0.01$ \\
\hline & Laaka & $32.44 \pm 2.86$ & $0.14 \pm 0.02$ & $2.01 \pm 0.39$ & $3.25 \pm 0.62$ & $0.03 \pm 0.01$ \\
\hline & Kivi & $23.26 \pm 1.67$ & $0.31 \pm 0.05$ & $2.15 \pm 0.44$ & $2.37 \pm 0.52$ & $0.21 \pm 0.02$ \\
\hline
\end{tabular}

Under the limits of quantification results are indicated by <LOQ. Data sources for the elements: Finnish Environment Institute Water Quality Database (2017) and own measurements in 2013, 2014, and 2015

-Not analysed

$*_{n} n=1$, no standard error 
Table 4 Mean element concentrations $( \pm$ standard error, number of cases in parentheses) $\mathrm{mg} \mathrm{kg}^{-1}$ (dry weight) in the livers of the male perch caught 2013

\begin{tabular}{|c|c|c|c|c|c|}
\hline Lake & $\mathrm{Fe}$ & $\mathrm{Zn}$ & Mn & $\mathrm{Cd}$ & $\mathrm{S}$ \\
\hline Kiantajärvi & $\begin{array}{l}{ }^{\mathrm{a}} 264 \pm 24 \\
(n=4)\end{array}$ & $\begin{array}{l}130 \pm 10.9 \\
(n=4)\end{array}$ & $\begin{array}{l}{ }^{\mathrm{a}} 9.37 \pm 0.95 \\
(n=4)\end{array}$ & $\begin{array}{l}{ }^{\mathrm{a}} 2.13 \pm 0.45 \\
(n=4)\end{array}$ & $\begin{array}{l}8258 \pm 726 \\
(n=4)\end{array}$ \\
\hline Jormasjärvi & $\begin{array}{l}{ }^{\mathrm{b}} 585 \pm 63 \\
(n=15)\end{array}$ & $\begin{array}{l}147 \pm 8.3 \\
(n=15)\end{array}$ & $\begin{array}{l}{ }^{\mathrm{a}} 9.55 \pm 0.58 \\
(n=15)\end{array}$ & $\begin{array}{l}{ }^{c} 23.4 \pm 2.07 \\
(n=15)\end{array}$ & $\begin{array}{l}8732 \pm 330 \\
(n=15)\end{array}$ \\
\hline Laakajärvi & $\begin{array}{l}{ }^{\mathrm{bc}} 905 \pm 183 \\
(n=2)\end{array}$ & $\begin{array}{l}127 \pm 5.8 \\
(n=2)\end{array}$ & $\begin{array}{l}{ }^{\mathrm{b}} 14.65 \pm 4.31 \\
(n=2)\end{array}$ & $\begin{array}{l}{ }^{\mathrm{a}} 3.87 \pm 1.03 \\
(n=2)\end{array}$ & $\begin{array}{l}9857 \pm 739 \\
(n=2)\end{array}$ \\
\hline Kivijärvi & $\begin{array}{l}{ }^{\mathrm{c}} 1412 \pm 267 \\
(n=5)\end{array}$ & $\begin{array}{l}157 \pm 10.9 \\
(n=5)\end{array}$ & $\begin{array}{l}{ }^{\mathrm{b}} 15.01 \pm 1.19 \\
(n=5)\end{array}$ & $\begin{array}{l}{ }^{\mathrm{b}} 12.34 \pm 2.74 \\
(n=5)\end{array}$ & $\begin{array}{l}10,195 \pm 620 \\
(n=5)\end{array}$ \\
\hline ANOVA $F$ & 16.800 & 0.906 & 6.122 & 36.112 & 2.183 \\
\hline$p$ & $<0.001$ & 0.454 & 0.003 & $<0.001$ & 0.119 \\
\hline
\end{tabular}

Observations below the LOQ were discarded from the calculations. ANOVA $F$ and statistical significances $(p)$ are given in the last row of the table. Superscript letters before the means represent statistically significant differences between the lakes (LSD pairwise comparison, different letters indicate statistically significant difference, $p<0.05$ ). Statistical analyses were made with $\log _{10}$-transformed values
MI on the lakes. In Kivijärvi, the Mn concentration of perch livers differed from the Mn concentrations in Kiantajärvi and Jormasjärvi. The lake-wise comparisons revealed that the males from Jormasjärvi and Kivijärvi had significantly higher liver $\mathrm{Cd}$ concentrations than the perch in Kiantajärvi and Laakajärvi. The highest $\mathrm{Cd}$ concentrations were not found in the most significantly impacted lake. The liver $\mathrm{Zn}$ and $\mathrm{S}$ concentrations did not differ significantly between the lakes (Table 4).

There were no significant differences in muscle Fe, Zn, and $\mathrm{Ni}$ concentrations among the lakes (Table 5). The significantly different muscle $\mathrm{S}$ concentrations among the lakes (Table 5) showed that perch in Kivijärvi had significantly higher concentrations of $\mathrm{S}$ in their muscle than perch in the reference lake Kiantajärvi and Jormasjärvi.

The Fe concentration of the liver correlated negatively with the wet mass of liver and testes (Pearson $r=-0.551$, $p=0.004, n=26$ and $r=-0.629, p=0.001, n=26$ ). Also, the muscle Fe concentration correlated negatively with the liver mass $(r=-0.303, p=0.038, n=47)$ but not with the testes mass ( $r=-0.170, p=0.255, n=47)$. The muscle $\mathrm{S}$ concentration correlated negatively with the wet mass of liver and testes (Pearson $r=-0.307, p=0.036, n=47$ and $r=-0.356, p=0.014, n=47)$. The $\mathrm{Cd}, \mathrm{Mn}$, and $\mathrm{Zn}$ concentrations of both tissues and the liver $\mathrm{S}$ concentration did not correlate with the liver or testes mass $(p>0.05)$.

\section{Condition of Perch}

The wet masses of carcass differed significantly between the perch males in the study lakes (Fig. 3a, ANCOVA, $F=9.363, d f=(3,245), p<0.001)$, the males in the reference lake, Kiantajärvi, which had significantly higher wet mass than males in the MI lakes (LSD pairwise comparison, $p<0.05)$. Both the sampling year and the covariate total length of fish was statistically significant $(p<0.001)$. The interaction between lake and year was significant $(p<0.001)$, because in Kiantajärvi in 2014, the wet mass was higher than in 2013, whereas in the MI lakes the wet mass was similar in both years. The lake-wise difference in
Table 5 Mean element concentrations $( \pm$ SE, number of cases in parentheses,) $\mathrm{mg} \mathrm{kg}^{-1}$ (dry weight) in the muscles of the male perch caught 2013. Observations below the LOQ were discarded from the calculations

\begin{tabular}{|c|c|c|c|c|c|}
\hline & $\mathrm{Fe}$ & $\mathrm{Zn}$ & $\mathrm{Mn}$ & $\mathrm{Ni}$ & $\mathrm{S}$ \\
\hline Kiantajärvi & $\begin{array}{l}14.59 \pm 4.84 \\
(n=5)\end{array}$ & $\begin{array}{l}26.80 \pm 3.88 \\
(n=5)\end{array}$ & - & $\begin{array}{l}1.13 \pm 0.16 \\
(n=4)\end{array}$ & $\begin{array}{l}{ }^{\mathrm{a}} 9782 \pm 744 \\
(n=5)\end{array}$ \\
\hline Jormasjärvi & $\begin{array}{l}19.27 \pm 4.22 \\
(n=16)\end{array}$ & $\begin{array}{l}26.08 \pm 4.41 \\
(n=17)\end{array}$ & $\begin{array}{l}1.19 \pm 0.56 \\
(n=5)\end{array}$ & $\begin{array}{l}1.14 \pm 0.19 \\
(n=16)\end{array}$ & $\begin{array}{l}{ }^{\mathrm{a}} 9983 \pm 352 \\
(n=17))\end{array}$ \\
\hline Laakajärvi & $\begin{array}{l}17.46 \pm 3.9 \\
(n=10)\end{array}$ & $\begin{array}{l}20.82 \pm 2.35 \\
(n=10)\end{array}$ & $\begin{array}{l}9.79 \pm 4.82 \\
(n=5)\end{array}$ & $\begin{array}{l}0.98 \pm 0.54 \\
(n=5)\end{array}$ & $\begin{array}{l}{ }^{\mathrm{ab}} 10944 \pm 531 \\
(n=9)\end{array}$ \\
\hline Kivijärvi & $\begin{array}{l}17.38 \pm 2.01 \\
(n=16)\end{array}$ & $\begin{array}{l}21.17 \pm 2.22 \\
(n=16)\end{array}$ & $\begin{array}{l}1.55 \\
(n=1)\end{array}$ & $\begin{array}{l}1.38 \pm 0.23 \\
(n=11)\end{array}$ & $\begin{array}{l}\mathrm{b} 11685 \pm 258 \\
(n=16)\end{array}$ \\
\hline ANOVA $F$ & 0.487 & 0.543 & - & 0.800 & 4.935 \\
\hline$p$ & 0.693 & 0.655 & & 0.503 & 0.005 \\
\hline
\end{tabular}

ANOVA $F$ and statistical significances $(p)$ are given in the last row of the table. Superscript letters before the means represent statistically significant differences between the lakes (LSD pairwise comparison, different letters indicate statistically significant difference, $p<0.05)$. Statistical analyses were made with $\log _{10}$-transformed values

-Not analyzed 

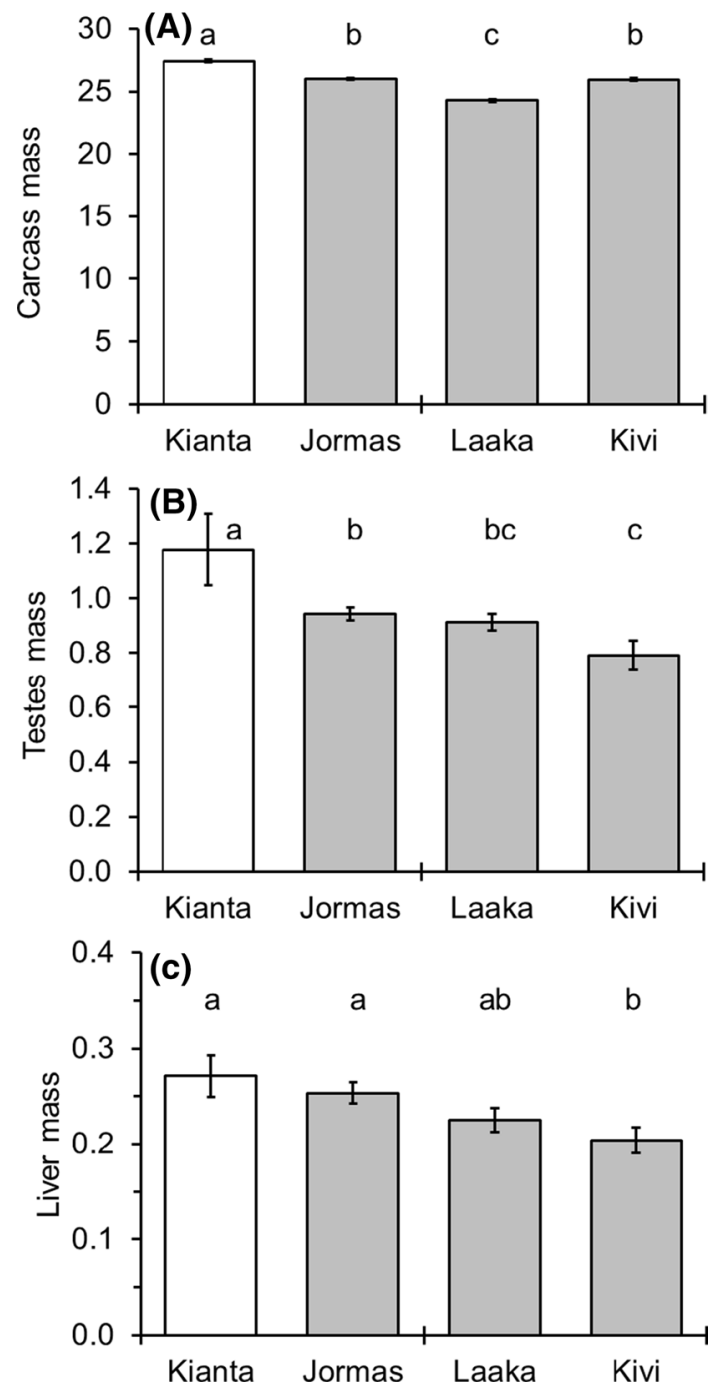

Fig. 3 Estimated marginal means wet mass (g) of carcass (a), testes (b), and liver (c) of perch male caught from the reference (open bar) and mining impacted lakes in 2013 and 2014. Vertical lines represent 95\% confidence intervals and letters above the bars statistically significant differences between the lakes (LSD paired comparison, different letters indicate statistically significant difference, $p<0.05$ )

testes mass was significant (ANCOVA, $F=6.134, d f=(3$, $242), p<0.001)$, and the total length was a significant covariate $(p>0.001)$ while the year was not $(p=0.102)$. Males from Kiantajärvi had the highest mean wet mass of testes, which was significantly higher than the testes of males from the MI lakes (Fig. 3b, LSD pairwise comparison, $p<0.05)$. The wet mass of liver of the perch males differed significantly among lakes (Fig. 3c, ANCOVA, $F=2.719, d f=(3,236), p=0.045)$ and the covariate-total length of fish-also was highly significant $(p<0.001)$. The liver masses of the Kivijärvi perch were lower than the liver masses in the reference lake (LSD pairwise comparison, $p=0.024)$.

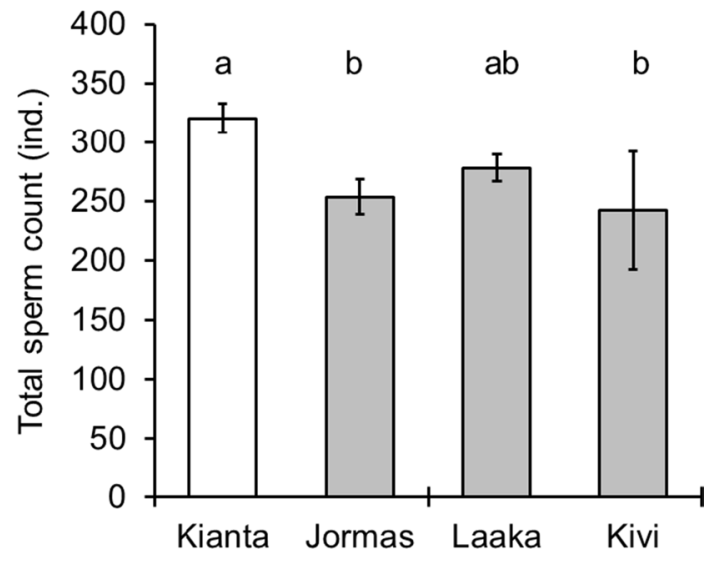

Fig. 4 Total mean sperm count (individuals) of perch caught in 2013 from the reference (open) and mining impacted lakes. Vertical lines represent the standard error of mean and letters above the bars statistically significant differences between the lakes (LSD paired comparison, different letters indicate statistically significant difference, $p<0.05)$

\section{Sperm Counts and Motility}

The sperm counts of the perch varied significantly among the lakes (Fig. 4, ANOVA, $F=5.244, d f=(3,61), p=0.003)$; the reference lake males had significantly higher sperm counts than males in Jormasjärvi and Kivijärvi (LSD paired comparison, $p<0.001$ ). A statistical significance ( $p$ value) for the difference in sperm count between Kiantajärvi and Laakajärvi by LSD comparison was 0.081 . The sperm counts of males between the MI lakes did not differ significantly (LSD pairwise comparison, $p>0.1$ ). The sperm count was not in relation to the wet mass of the males (Spearman's $r=0.204, n=61, p=0.116$ ) or the proportion of active sperm in samples (Spearman's $r=0.043, n=61, p=0.740$ ).

The proportion of motile sperm differed significantly among the different types of activation waters (repeated measures ANOVA, $F=13.543, d f=(2,56), p<0.001)$. Artificial freshwater and lake water treatments did not differ significantly (Bonferroni, $\mathrm{MD}=0.022, p=1.000$ ), but they both had significantly higher proportions of motile sperm compared with the Cd treatment (Bonferroni, $\mathrm{MD}=0.205-0.226$, $p \leq 0.001$ ).

In the sperm measurements taken $10 \mathrm{~s}$ after the sperm activation with the natal lake water of the fish, the lakewise comparisons showed significant differences in the perch sperm motility among the different lakes (Fig. 5a, ANOVA, $F=3.400, d f=(3,61), p=0.024)$. In the reference lake, Kiantajärvi, the perch males had statistically significantly lower proportion of motile sperm compared with males in MI lakes (LSD pairwise comparison, $p<0.05)$. Similarly, the VSL of sperm differed significantly among the lakes (Fig. 5b, ANOVA, $F=2.398$, $d f=(4,66), p=0.059)$ being lower in Kiantajärvi and 


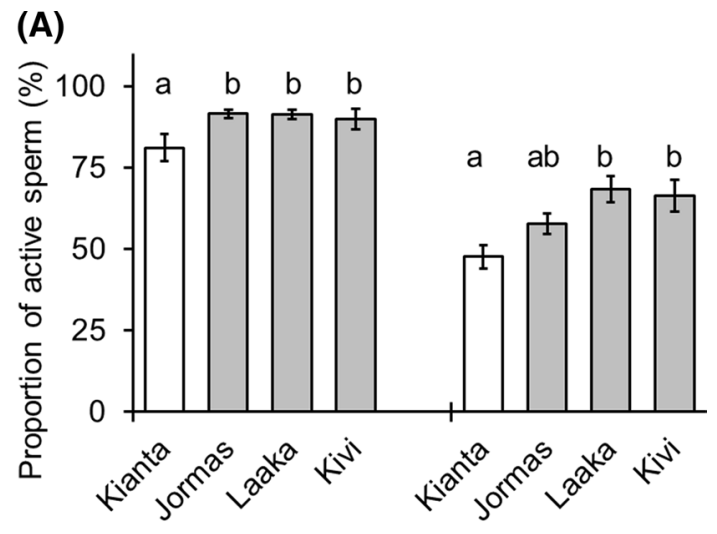

(B)

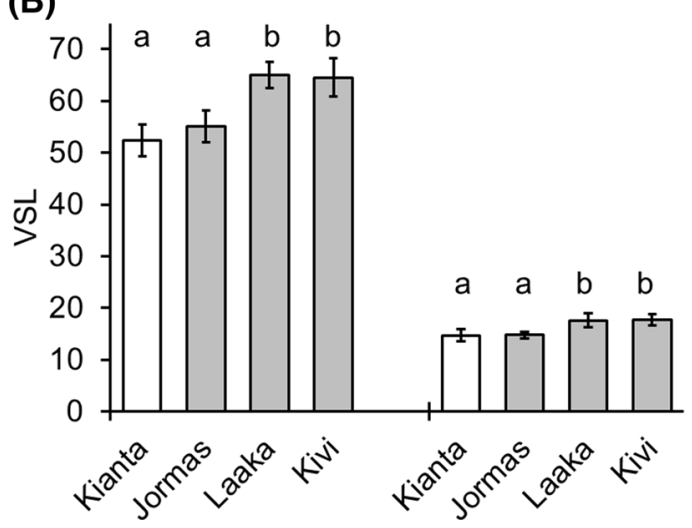

Fig. 5 Relative proportion of active sperm (a, \%) and velocity (b, VSL, $\mu \mathrm{m} \mathrm{s}^{-1}$ ) of a sperm head along the straight line between its first detected position and its last position in the sperm activation test of perch with activation by lake water from each fish's natal lake in the sampling occasions of $10 \mathrm{~s}$ (4 bars in left) and $20 \mathrm{~s}$ (4 bars in right). Vertical lines represent the standard error of mean and letters above the bars statistically significant differences between the lakes (LSD paired comparison, different letters indicate statistically significant difference, $p<0.05$ )

Jormasjärvi than in Laakajärvi and Kivijärvi (LSD pairwise comparison, $p<0.05)$. In the subsequent sperm measurements taken $10 \mathrm{~s}$ later, the proportion of motile perch sperm differed significantly between the lakes (Fig. 5a, ANOVA, $F=5.051, d f=(3,61), p=0.004)$. In the Kiantajärvi, the perch males had statistically significantly lower proportion of motile sperm compared with males in Laakajärvi and Kivijärvi (LSD paired comparison, $p=0.002$ ). A statistical significance ( $p$ value) for the difference in sperm motility between Kiantajärvi and Jormasjärvi by a LSD pairwise comparison was 0.059 . The VSL of sperm differ significantly among the lakes (Fig. 5b, ANOVA, $\mathrm{F}=2.885, d f=(3,61), p=0.043)$ : lower in Kiantajärvi and Jormasjärvi than in Laakajärvi and Kivijärvi (LSD pairwise comparison, $p<0.05$ ).

\section{Discussion}

The mining effluent induced salinity and metal contamination was evident in the three MI study lakes, particularly in Kivijärvi. Contamination affected the liver tissue concentrations of perch males but in general not the muscle concentrations, except that the S concentration of Kivijärvi was higher than muscle $S$ in Kiantajärvi and Jormasjärvi. In our study lakes, $\mathrm{Fe}$ and $\mathrm{Zn}$ had the highest concentrations of the measured metals in liver and muscle of perch. Liver Fe concentration in the MI lakes varied from 323 to $2326 \mathrm{mg} \mathrm{kg}^{-1}$ and from 5 to $77 \mathrm{mg} \mathrm{kg}^{-1}$ in muscle tissue. In other metal polluted lakes, the range of $\mathrm{Fe}$ concentrations in liver and muscle of different fish species has been reported to be $50-4020 \mathrm{mg} \mathrm{kg}^{-1}$ and $4-100 \mathrm{mg} \mathrm{kg}^{-1}$, respectively (Honda et al. 1983; Szarek-Gwiazda et al. 2006; Rajkowska and Protasowicki 2013; El-Moselhy et al. 2014; Mohamed et al. 2016), whereas the $\mathrm{Zn}$ concentrations in liver and muscle have been $60-320 \mathrm{mg} \mathrm{kg}^{-1}$ and 1-50 mg kg-1, respectively (Honda et al. 1983; Tkatcheva et al. 2000; Eastwood and Couture 2002; Rajkowska and Protasowicki 2013; El-Moselhy et al. 2014; Yancheva et al. 2014). In our MI lakes, the $\mathrm{Zn}$ range was $108-213$ in fish livers and 10-85 in muscles.

Metal exposure has been observed to cause changes in hepatic tissue (Tkatcheva et al. 2000; El-Moselhy et al. 2014; Yancheva et al. 2014; Abalaka 2015; Mohamed et al. 2016). Especially Cd (Tkatcheva et al. 2000), Cu, and Fe exposure (Mohamed et al. 2016) have caused liver cell damage, such as apoptosis, necrosis, fibrosis, and hepatocyte lysis. Jezierska and Witeska (2006) noted in their review that various studies have shown synergistic or additive effects of metals in fish. In our study, no histological analyses of hepatic tissue were performed, but the perch males from the MI lakes had smaller livers than fish caught from the reference lake, suggesting harmful effects of the metal and salinity contamination of these lakes to perch males.

Smaller livers, testes, and lower wet carcass mass in relation to the length of fish may suggest low food availability and/or harmful shifts in prey availability and subsequent higher-energy demand in our MI study lakes under unstable multi-stressor conditions. In an earlier study with golden perch (Macquaria ambigua), starvation has been demonstrated to decrease the hepatosomatic index and increase the utilization of liver energy reserves (Collins and Anderson 1995). The diversity of the benthic macroinvertebrate communities can be reduced in metal-contaminated lakes, and the lack of suitable prey for diet shift can increase the activity costs and cause slow growth and even stunting of the fish, as observed with yellow perch (Sherwood et al. 2002; Iles and Rasmussen 2005). Additionally, 
Sherwood et al. (2000) have demonstrated that the food conversion efficiency to growth has been reduced in yellow perch in metal contaminated lakes. Similarly, Overton et al. (2008) suggested that the observed growth impairment in Eurasian perch exposed to increased water salinity (10\%) may have been linked to the reduced allocation of food to growth. Behavior of fish also has showed to be affected by the impairment of their sensory neurons with behavioral deficits under metal contamination (Dew et al. 2014), which may influence seriously their capability to observe their environment and diminish the antipredator behavior, survival, and likely on their growth. In all, in several studies, the increased tissue metal concentrations have been associated with the decrease in the condition and growth of fish (Levesque et al. 2002; Rajotte and Couture 2002).

In our MI study lakes, the significantly lower sperm counts and testes size of the perch males suggested that the mining effluent contamination have disturbed their investments to the reproduction, probably due to repeated chronic multi-stressor conditions in water quality. For example, Campbell et al. (1992) have demonstrated lower sperm densities in rainbow trout (Oncorhynchus mykiss) when they have been repeatedly exposed to stressful anoxic treatment. In our study lakes, the lower sperm counts seemed to be compensated by investing in sperm quality, as the proportion of motile sperm and the linear swimming velocity (VSL) of the sperm was higher in the males of the MI lakes than in the males of the reference group. A similar relationship between the sperm density and active sperm has been found with haddock (Melanogrammus aeglefinus): when the spermatocrit exceeded $70 \%$, the proportion of motile sperm was decreased (Rideout et al. 2004). The quality of gametes is an important trait affecting the reproductive success and maximizing fitness of fish, and several environmental factors regulate the energy allocation to the reproductive products (Wootton 1998). Hutchings (1991) showed that female brook trout (Salvelinus fontinalis) produce small number of large eggs under low food conditions and many small eggs under high food conditions. Our results propose similar association between sperm quantity and quality. In other studies, the gonadosomatic index of male yellow perch (Perca flavescens) have been observed to be lowered in metal contaminated lakes (Levesque et al. 2002; Pyle et al. 2005). In these Canadian lakes, the free metal ion or total $\mathrm{Cd}, \mathrm{Ni}$, and $\mathrm{Zn}$ concentrations were at the same level or lower than the dissolved concentrations in our MI study lakes.

The perch sperm did not seem to be highly sensitive to activation water-mediated, short-term exposure to water containing elevated concentrations of metals. From the tested activation waters, only the artificial freshwater spiked water with extremely high $\mathrm{Cd}$ concentration $\left(50 \mathrm{mg} \mathrm{L}^{-1}\right)$ reduced the proportion of motile sperm. Similar high tolerance of fish sperm to short-term exposure of several different metals has been observed earlier by Lahnsteiner et al. (2004) for different fish species.

In the contaminated study lakes, the measured characteristics of hepatic, somatic, and reproductive tissues of perch males have been altered under the multi-stressor conditions caused by increased metal concentrations and elevated salinity. The measured growth and condition variables are sensitive to many randomly or systematically varied withinlake and interlake factors, i.e., population dynamics of food organisms, internal annual cycles in the perch population dynamics, length of growing season in relation to annual phenology and water temperature, and other anthropogenic changes in the catchment area of the lakes. Although our research design includes only one reference lake of four lakes and each contaminated lakes with different contamination profile and other morph-edaphic features, the results suggested that condition and sperm measures of fish could be useful indicators for metal mining impacts on freshwater fish, but only if high natural interlake and phenological variation in these characteristics can be controlled by a multiyear monitoring design.

Acknowledgements Open access funding provided by University of Jyväskylä (JYU).

Funding This study was supported by the Academy of Finland (Grants 281800, 285296), Finnish Doctoral Programme on Environmental Science and Technology (EnSTe), Emil Aaltonen Foundation and Olvi Foundation.

Availability of Data and Material The datasets generated during and/or analysed during the current study are available from the corresponding author on reasonable request.

\section{Compliance with Ethical Standards}

Conflict of interest Any of authors have no conflicts of interest.

Human and Animal Rights Sampling and handling of fish have been done according to the guidelines for experimental animals. Fishing right owners have permitted the catching of the fish.

Open Access This article is licensed under a Creative Commons Attribution 4.0 International License, which permits use, sharing, adaptation, distribution and reproduction in any medium or format, as long as you give appropriate credit to the original author(s) and the source, provide a link to the Creative Commons licence, and indicate if changes were made. The images or other third party material in this article are included in the article's Creative Commons licence, unless indicated otherwise in a credit line to the material. If material is not included in the article's Creative Commons licence and your intended use is not permitted by statutory regulation or exceeds the permitted use, you will need to obtain permission directly from the copyright holder. To view a copy of this licence, visit http://creativecommons.org/licenses/by/4.0/. 


\section{References}

Abalaka SE (2015) Heavy metals bioaccumulation and histopathological changes in Auchenoglanis occidentalis fish from Tiga dam, Nigeria. J Environ Health Sci Eng 13:67. https://doi.org/10.1186/ s40201-015-0222-y

Anonymous (1996) Water quality determination of the inhibition of the mobility of Daphnia magna Strauss (Cladocera, Crustacea). Acute toxicity test. SFS-EN ISO 6341:1996

Arola HE, Karjalainen J, Vehniäinen E-R, Väisänen A, Kukkonen JVK, Karjalainen AK (2017) Tolerance of whitefish (Coregonus lavaretus) early life stages to manganese sulfate is affected by the parents. Environ Toxicol Chem 36:343-353

Bourret V, Couture P, Campbell PGC, Bernatchez L (2008) Evolutionary ecotoxicology of wild yellow perch (Perca flavescens) populations chronically exposed to a polymetallic gradient. Aquat Toxicol 86:76-90

Campbell PM, Potfinger TG, Sumpter JP (1992) Stress reduces the quality of gametes produced by rainbow trout. Biol Reprod 47:1140-1150

Collins AL, Anderson TA (1995) The regulation of endogenous energy stores during starvation and refeeding in the somatic tissues of the golden perch. J Fish Biol 47:1004-1015

Couture P, Busby P, Gauthier C, Rajotte JW, Pyle GG (2008) Seasonal and regional variations of metal contamination and condition indicators in yellow perch (Perca flavescens) along two polymetallic gradients. I. Factors influencing tissue concentrations. Metal Hum Ecol Risk Assess 14:97-125

De La Calle I, Cabaleiro N, Lavilla I, Bendicho C (2009) Analytical evaluation of a cup-horn sonoreactor used for ultrasound-assisted extraction of trace metals from troublesome matrices. Spectrochim Acta Part B 64:874-883

Dew WA, Azizishirazi A, Pyle GG (2014) Contaminant-specific targeting of olfactory sensory neuron classes: connecting neuron class impairment with behavioural deficits. Chemosphere 112:519-525

Durrant CJ, Stevens JR, Hogstrand C, Bury N (2011) The effect of metal pollution on the population genetic structure of brown trout (Salmo trutta L.) residing in the River Hayle, Cornwall, UK. Environ Pollut 159:3595-3603

Eastwood S, Couture P (2002) Seasonal variations in condition and liver metal concentrations of yellow perch (Perca flavescens) from a metal-contaminated environment. Aquat Toxicol 58:43-56

El-Moselhy KM, Othamn AI, El-Azem HA, El-Metwally ME (2014) Bioaccumulation of heavy metals in some tissues of fish in the Red Sea, Egypt. Egypt J Basic Appl Sci 1:97-105

Finnish Environment Institute Database (2017) Finnish Environment Institute and Centres for Economic Development, Transport and the Environment. http://www.syke.fi/avoindata. Accessed 10 Nov 112017

Honda K, Sahrul M, Hidaka H, Tatsukawa R (1983) Organ and tissue distribution of heavy metals, and their growth-related changes in antarctic fish, Pagothenia borchgrevinki. Agric Biol Chem 47:2521-2532

Hutchings JA (1991) Fitness consequences of variation in egg size and food abundance in brook trout Salvelinus fontinalis. Evolution 45:1162-1168

Iles AC, Rasmussen JB (2005) Indirect effects of metal contamination on energetics of yellow perch (Perca flavescens) resulting from food web simplification. Freshw Biol 50:976-992

Jezierska B, Witeska M (2006) The metal uptake and accumulation in fish living in polluted waters. In: Twardowska I, Allen HE, Häggblom MM, Stefaniak S (eds) Soil and water pollution monitoring, protection and remediation. Springer, Berlin, pp 3-23

Kauppi S, Mannio J, Hellsten S, Nystén T, Jouttijärvi T, Huttunen M, Ekholm P, Tuominen S, Porvari P, Karjalainen A, Sara-Aho T,
Saukkoriipi J, Maunula M (2013) Assessment of the potential impacts on water environment caused by the gypsum pond leakage at the Talvivaara mine. Rep Finnish Environ Inst 11(2013):1-90 [in Finnish with English abstract]

Kime DE, Ebrahimi M, Nysten K, Roelants I, Rurangwa E, Moore HD, Ollevier F (1996) Use of computer assisted sperm analysis (CASA) for monitoring the effects of pollution on sperm quality of fish; application to the effects of heavy metals. Aquat Toxicol 36:223-237

Lahnsteiner F, Mansour N, Berger B (2004) The effect of inorganic and organic pollutants on sperm motility of some freshwater teleosts. J Fish Biol 65:1283-1297

Leppänen JJ, Weckström J, Korhola A (2017) Multiple mining impacts induce widespread changes in ecosystem dynamics in a boreal lake. Nat Sci Rep 7:1-11

Levesque HM, Moon TW, Campbell PGC, Hontela A (2002) Seasonal variation in carbohydrate and lipid metabolism of yellow perch (Perca flavescens) chronically exposed to metals in the field. Aquat Toxicol 60:257-267

Mohamed SA, Elshal MF, Kumosani TA, Mal AO, Ahmed YA, Almulaiky YA, Asseri AH, Zamzami MA (2016) Heavy metal accumulation is associated with molecular and pathological perturbations in liver of Variola louti from the Jeddah Coast of Red Sea. Int J Environ Res Public Health 13:342. https://doi. org/10.3390/ijerph13030342

Overton JL, Bayley M, Paulsen H, Wang T (2008) Salinity tolerance of cultured Eurasian perch, Perca fluviatilis L.: effects on growth and on survival as a function of temperature. Aquaculture 277:282-286

Pyle GG, Rajotte JW, Couture P (2005) Effects of industrial metals on wild fish populations along a metal contamination gradient. Ecotoxicol Environ Saf 61:287-312

Quintero-Moreno A, Miro J, Rigau TA, Rodriguez-Gil JE (2003) Identification of sperm subpopulations with specific motility characteristics in stallion ejaculates. Theriogenology 59:1973-1990

Rajkowska M, Protasowicki M (2013) Distribution of metals (Fe, Mn, $\mathrm{Zn}, \mathrm{Cu}$ ) in fish tissues in two lakes of different trophy in Northwestern Poland. Environ Monit Assess 185:3493-3502

Rajotte JW, Couture P (2002) Effects of environmental metal contamination on the condition, swimming performance, and tissue metabolic capacities of wild yellow perch (Perca flavescens). Can J Fish Aquatic Sci 59:1296-1304

Rideout RM, Trippel EA, Litvak MK (2004) Relationship between sperm density, spermatocrit, sperm motility and spawning date in wild and cultured haddock. J Fish Biol 65:319-332

Riekkola-Vanhanen M (2013) Talvivaara mining company: from a project to a mine. Min Eng 48:2-9

Rurangwa E, Roelants I, Huyskens G, Ebrahimi M, Kime DE, Ollevier F (1998) The minimum effective spermatozoa: egg ratio for artificial insemination and the effects of mercury on sperm motility and fertilization ability in Clarias gariepinus. J Fish Biol 53:402-413

Salmelin J, Leppänen MT, Karjalainen AK, Vuori K-M, Gerhardt A, Hämäläinen H (2017) Assessing ecotoxicity of biomining effluents in stream ecosystems by in situ invertebrate bioassays: a case study in Talvivaara, Finland. Environ Toxicol Chem 36:147-155

Sherwood GD, Rasmussen JB, Rowan DJ, Brodeur J, Hontela A (2000) Bioenergetic costs of heavy metal exposure in yellow perch (Perca flavescens): in situ estimates with a radiotracer $\left({ }^{137} \mathrm{Cs}\right)$ technique. Can J Fish Aquatic Sci 57:441-450

Sherwood GD, Kovecses J, Hontela A, Rasmussen JB (2002) Simplified food webs lead to energetic bottlenecks in polluted lakes. Can J Fish Aquatic Sci 59:1-5

Tkatcheva V, Holopainen IJ, Hyvärinen H (2000) Heavy metals in perch (Perca fluviatilis) from the Kostomuksha region (N-western Karelia, Russia). Boreal Environ Res 5:209-220 
US-EPA (2001) Trace elements in water, solids, and biosolids by inductively coupled plasma-atomic emission spectrometry. USEPA Method 200.7 Revision 4.4:1-57

Wallin J (2018) Aquatic effects and risk assessment of multi-metal leachates from metal mining and acid sulphate soils. JYU dissertations 9. http://urn.fi/URN:ISBN:978-951-39-7527-2
Wootton RJ (1998) Ecology of teleost fishes. Fish Fish Ser 24:1-386 Yancheva VS, Georgieva ES, Velcheva IG, Iliev IN, Vasileva TA, Petrova ST, Stoyanova SG (2014) Biomarkers in European perch (Perca fluviatilis) liver from a metal-contaminated dam lake. Biologia 69:1615-1624 